\title{
Process Oriented Guided Inquiry Learning as an Innovative Teaching Method in Clinical Biochemistry: Piloting of the Process
}

\author{
Gayathri Balasubramaniam \\ Department of Biochemistry, PSG Institute of Medical Sciences and Research, India
}

\begin{tabular}{ll}
\hline ARTICLE INFO \\
Received & $: 15 / 12 / 2014$ \\
Accepted & $: 13 / 03 / 2015$ \\
Published & $: 10 / 06 / 2015$
\end{tabular}

\section{KEYWORD}

Guided Inquiry

Self-directed learning

Critical thinking

POGIL

\section{ABSTRACT}

Current teaching practices in clinical Biochemistry are focused on didactic lectures. It minimizes the understanding, retention of the subject and hence disengages the students from the learning process. Due to this the application of knowledge and problem solving skills among students are greatly reduced. Introduction of Process Oriented Guided Inquiry Approach (POGIL) an Innovative method in clinical Biochemistry teaching enhances the basic learning and problem solving skills in students. Introduced to teach diabetes mellitus in two sessions among students, POGIL was found successful. After the POGIL sessions, the student's performance improved markedly and they felt confident in their knowledge in diabetes mellitus. It also improved the communication skills, critical thinking and problem solving skills in students. This method if employed in successful years among larger volume of students shall be a very effective innovative teaching-learning method in clinical biochemistry.

(C) Medical Education Department, School of Medical Sciences, Universiti Sains Malaysia. All rights reserved.

CORRESPONDING AUTHOR: Gayathri Balasubramaniam, Associate Professor, Department of Biochemistry, PSG Institute of Medical Sciences and Research, India.

Email: drgayathrikeerthivasan@gmail.com

\section{Introduction}

Current teaching strategies in first year MBBS clinical biochemistry class rooms are more focused on didactic lectures. This minimizes the level of student understanding, comprehension and disengages students from the learning process causing information to be quickly forgotten. Process oriented Guided Inquiry Learning (POGIL) - a self-managed, student centred learning cycle format as an innovative strategy focuses on core concepts, encourages deep understanding of the subject and develop higher order thinking skills among students. POGIL in clinical biochemistry encourages full participation and accountability by each student. This transforms students into self-directed learners and promotes them to be better physicians (1). With the effectiveness of POGIL in chemistry previously proved (2), here we introduce an application of guided inquiry approach in teaching diabetes mellitus through POGIL sessions to enhance the basic learning and problem solving skills in clinical biochemistry among first year MBBS students.

\section{Method}

Two POGIL modules on diabetes mellitus consisting of clinical problems, student's and facilitator's guide and a list of learning objectives were developed and administered to a small batch of six first year MBBS students after 
they had undergone a routine lecture teaching session on diabetes mellitus.

The learning outcomes of the modules were,

1. Apply your understanding on the metabolic changes in DM.

2. Explain the metabolic basis for the complications of DM.

3. Interpretation of the clinical data with clinical features and diagnosis of DM.
4. Integrate the understanding of DM with the development of complications of DM.

The plan of a POGIL teaching session with specific roles of the students is given in table 1.

After routine lecture class, a questionnaire was administered to evaluate the performance of students. After the conduct of two POGIL sessions, a post test questionnaire was administered.

Table 1: Outline of a POGIL teaching session

\begin{tabular}{|c|c|c|c|}
\hline Steps in POGIL learning process & Teacher's role & Component of the activity & Class Schedule \\
\hline Identify a need to learn & Engage & $\begin{array}{l}\text { An issue of Interest is given. } \\
\text { Learning objectives are defined. }\end{array}$ & 10 minutes \\
\hline Connect to prior understandings & Elicit & $\begin{array}{l}\text { A question or issue is raised, student's } \\
\text { explanations are sought }\end{array}$ & 10 minutes \\
\hline Explore & Explore & $\begin{array}{l}\text { A task is provided. Resource material is } \\
\text { identified. Students explore the model in } \\
\text { response to critical thinking questions. }\end{array}$ & 25 minutes \\
\hline $\begin{array}{l}\text { Concept invention, introduction } \\
\text { and formation }\end{array}$ & Explain & $\begin{array}{l}\text { Critical thinking questions which lead to } \\
\text { identification of concepts and understanding is } \\
\text { developed. }\end{array}$ & 20 minutes \\
\hline Practice applying knowledge & & $\begin{array}{l}\text { Skill exercises involve the application of the } \\
\text { knowledge. }\end{array}$ & 20 minutes \\
\hline Apply knowledge in new contexts & $\begin{array}{l}\text { Elaborate and } \\
\text { Extend }\end{array}$ & Extended problems require transfer of concepts & 15 minutes \\
\hline Reflect on the process & Evaluate & $\begin{array}{l}\text { Problem solutions and answers to questions are } \\
\text { validated and integrated with concepts. Learning } \\
\text { and performance assessed. }\end{array}$ & 20 minutes \\
\hline
\end{tabular}

The team roles included manager, recorder, spokesperson, reflector, skeptic and optimist.

Table 2: Student's perceptions on learning gains in POGIL sessions

\begin{tabular}{|c|c|c|c|c|c|c|}
\hline \multirow[b]{2}{*}{ To what degree do you agree with the following statements? } & \multicolumn{6}{|c|}{ Levels, \% } \\
\hline & 5 & 4 & 3 & 2 & 1 & NA \\
\hline 1. The course materials helped me to prepare for the activity & 67 & 33 & 0 & 0 & 0 & 0 \\
\hline 2. The activities in POGIL helped me better understand the subject & 84 & 0 & 16 & 0 & 0 & 0 \\
\hline 3. Working with peers improved the skill of problem solving & 100 & 0 & 0 & 0 & 0 & 0 \\
\hline 5. Working with peers helped to solve complicated problems & 67 & 33 & 0 & 0 & 0 & 0 \\
\hline 6. Feedback on activities helped to understand the concepts & 100 & 0 & 0 & 0 & 0 & 0 \\
\hline 7. Working in groups made me less likely to give up on difficult problems & 84 & 16 & 0 & 0 & 0 & 0 \\
\hline 8. Working with peers outside of class helped me understand concepts & 67 & 33 & 0 & 0 & 0 & 0 \\
\hline 9. POGIL sessions made me more responsible for my own learning & 100 & 0 & 0 & 0 & 0 & 0 \\
\hline 10. The textbook helped me understand the concepts after POGIL sessions & 67 & 0 & 33 & 0 & 0 & 0 \\
\hline 11. Learning is better in lecture classes & 16 & 0 & 0 & 84 & 0 & 0 \\
\hline \multicolumn{7}{|l|}{ To what extent did you make gains in the following as a result of POGIL sessions? } \\
\hline 1. Confidence in analyzing and interpreting data from the text & 84 & 16 & 0 & 0 & 0 & 0 \\
\hline 2. Confidence in my ability to solve new problems & 84 & 16 & 0 & 0 & 0 & 0 \\
\hline 3. Ability to think through a problem & 100 & 0 & 0 & 0 & 0 & 0 \\
\hline 4. Confidence in my ability to learn complex material & 67 & 33 & 0 & 0 & 0 & 0 \\
\hline 6. Ability to communicate through the sessions & 84 & 16 & 0 & 0 & 0 & 0 \\
\hline 8. Becoming a self-directed and self-reflective learner & 100 & 0 & 0 & 0 & 0 & 0 \\
\hline 10. Belief that I can learn and apply what I have learned in biochemistry & 100 & 0 & 0 & 0 & 0 & 0 \\
\hline 11. Tolerance of others/respect the opinion of others & 100 & 0 & 0 & 0 & 0 & 0 \\
\hline 12. Taking responsibility for my own learning & 100 & 0 & 0 & 0 & 0 & 0 \\
\hline
\end{tabular}

Levels: 5 - A great deal; 4 - A lot; 3 - Somewhat; 2 - A little; 1 - Not at all; NA - not applicable. 


\section{Results}

Direct comparison on the student's performance before and after POGIL sessions showed that there was a considerable improvement in both the scores and skills on problem solving that require complex cognitive skills after the POGIL sessions. The mean score of the students after the regular lecture session was $18 \pm 2.5$ and after POGIL session was $27 \pm 1.7$. Student's perceptions on learning gains in POGIL sessions based on Student Assessment of Learning Gains (3) are tabulated (Table-2)

\section{Discussion}

We have found that POGIL is ideally suited for teaching clinical Biochemistry among I MBBS students. The results and performance of the students after POGIL sessions in post-test questionnaire were significantly better when compared with traditional classes. The magnitude of knowledge, the development of problem solving skills and to address new critical problems in clinical Biochemistry poses a difficult task for the students. Course goal of POGIL (table-3) is set by incorporating Blooms levels (4) in exploration, concept invention and applications into the sessions. It created positive interdependence, individual accountability, mutual support of learning, collaborate skills and self-assessment, which was explained as five elements of cooperative learning in groups as out lined by Johnson and coworkers(2) and described by Hanson.(5)

Table 3: Course Goals in POGIL.

\begin{tabular}{llll}
\hline \multicolumn{1}{c}{ Cognitive } & \multicolumn{1}{c}{ Affective } & \multicolumn{1}{c}{ Social } & \multicolumn{1}{c}{ Lifelong learning } \\
\hline $\begin{array}{l}\text { 1. Acquire and master vocabulary } \\
\text { of biochemistry }\end{array}$ & $\begin{array}{l}\text { 1. Obtain a belief in one's ability to } \\
\text { learn and apply the material }\end{array}$ & $\begin{array}{l}\text { 1. Work cooperatively and } \\
\text { demonstrate commitment to a } \\
\text { group }\end{array}$ & $\begin{array}{l}\text { 1. Become self-directed: Initiate } \\
\text { the learning process }\end{array}$ \\
$\begin{array}{l}\text { 2. Organize information } \\
\begin{array}{l}\text { Understand complex relationships } \\
\text { in biochemistry }\end{array}\end{array}$ & $\begin{array}{l}\text { 2. Advance intellectual, tolerance } \\
\text { and integrity }\end{array}$ & $\begin{array}{l}\text { 2. Listen to and learn from } \\
\text { peers }\end{array}$ & $\begin{array}{l}\text { 2. Become self-reflective: } \\
\text { Review goals, purposes, } \\
\text { outcomes, and new learning }\end{array}$ \\
$\begin{array}{l}\text { 3. Improve visualization and } \\
\text { modeling skills }\end{array}$ & $\begin{array}{l}\text { 3. Set personal goals for } \\
\text { improvement and ask for help }\end{array}$ & 3.Value others & $\begin{array}{l}\text { 3. Become a self-assessor: Assess } \\
\text { one's own progress for strengths, } \\
\text { areas for improvement and } \\
\text { insights into the learning process } \\
\text { to continuously improve }\end{array}$ \\
$\begin{array}{l}\text { 4. Improve problem solving skills } \\
\text { by asking questions and examining } \\
\text { assumptions }\end{array}$ & &
\end{tabular}

5. Analyze and interpret data

Apply knowledge to new situations

6. Develop the ability to select appropriate actions and/or tools

Adopted from Lecture Free Biochemistry. A Process oriented guided Inquiry approach. Biochemistry and Molecular Biology Education.Minderhoutt et al (2007).

Almost all the students felt confident in understanding of biochemical concepts and applying it in clinical context, after POGIL sessions.

Students felt that they learn better when they are actively engaged in the structured learning format during the sessions, which improved their concept construction and understanding. About $84 \%$ of students reported that they developed greater confidence in analysis and interpretation of clinical biochemistry data. Students also felt that feedback given to during the sessions helped them to acquire complete knowledge about the subject and made them to connect to prior understandings. This made them to extend their knowledge base with new concepts and it also created a rich learning environment among them.

Although the small number of student respondents limits the statistical analysis of data, we believe the findings are relevant because the results reflect the student's responses in various aspects of POGIL. Most students find the POGIL sessions transform them into self-directed 
learners. With these observations and also with reports on previous studies (6), taking POGIL sessions for more number of clinical biochemistry teachings shall benefit the student community a lot.

\section{Conclusion}

Our implementation of POGIL in teaching diabetes mellitus in clinical biochemistry classes has been highly successful as evidenced by student's performance and their perception in acquiring higher order cognitive, social and affective skills. These skills would benefit the students greatly in their future professional lives.

\section{Reference}

1. D. Hanson, T. Wolfskill (2000) Process workshops-A new model for instruction, J. Chem. Educ. 77, 120-130.

2. D. W. Johnson, R. T. Johnson, K. A. Smith (1991) Cooperative Learning: Increasing College Faculty Instructional Productivity, The George Washington University, Graduate School of Education and Human Development, Washington, DC.

3. Student Assessment of Learning Gains. www.wcer.wisc.edu/ salgains/instructor/ (copyright 1997).

4. B. S. Bloom, M. D. Englehart, E. J. Furst, W. H. Hill, D. R. Krathwohl (1956) Taxonomy of Educational Objectives: The Classification of Educational Goals. Handbook 1: Cognitive Domain, David McKay, New York.

5. D. Hanson (2006) Instructor's Guide to Process-Oriented Guided-In-quiry Learning, Pacific Crest, Lisle, IL.

6. Vicky Minderhout, Jennifer Loertscher.(2007) Lecture Free Biochemistry. A process oriented Guided Inquiry Approach.35,3,172-180. 